\title{
Prevalence of abdominal aortic aneurysm and repair outcomes on the basis of patient sex: Should the timing of intervention be the same?
}

\author{
Nancy L. Harthun, MD \\ Vasana Cheanvechai, $M D^{\mathrm{b}}$ \\ Linda M. Graham, MD ${ }^{\mathrm{c}}$ \\ Julie A. Freischlag, MD ${ }^{d}$ \\ Vivian Gahtan, MD
}

See related editorials on pages 314,318 , and 322

From the Division of TCV Surgery, ${ }^{a}$ University of Virginia Health System, Charlottesville, Va; the Division of Vascular Surgery, ${ }^{\text {b }}$ University of Maryland, Baltimore, Md; the Department of Vascular Surgery, ${ }^{\mathrm{c}}$ the Cleveland Clinic Foundation, Cleveland, Ohio; the Department of Surgery, ${ }^{\mathrm{d}}$ Johns Hopkins School of Medicine, Baltimore, Md; and the Section of Vascular Surgery, ${ }^{e}$ Yale University School of Medicine, New Haven, Conn.

This is a project of the Society of Vascular Surgery, Committee on Women's Issues.

Received for publication Sept 29, 2003; accepted for publication Oct 6, 2003.

Address for reprints: Vivian Gahtan, MD, SUNY Upstate Medical University College of Medicine, Department of Surgery, 750 East Adams St, Syracuse, NY 13210 (Email: gahtanv@upstate.edu).

J Thorac Cardiovasc Surg 2004;127:325-8 $0022-5223 / \$ 30.00$

Copyright () 2004 by The American Association for Thoracic Surgery

doi:10.1016/j.jtcvs.2003.10.022

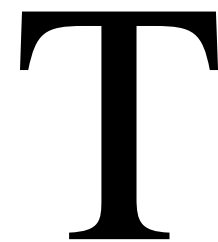

he prevalence of abdominal aortic aneurysms (AAAs) has been reported to be higher in men than in women. Most prevalence studies (AAA diagnosed by means of autopsy, ultrasound screening, and hospital discharge data) demonstrated the percentage of AAAs diagnosed in women to be $19 \%$ to $34 \%$ and the percentage diagnosed in men to be $66 \%$ to $81 \% .^{1-5}$ This rate appears to be reliably constant in many Western nations. No cause or causes for the dramatic difference in the prevalence of AAAs between the sexes has been identified.

Risk-factor profiles appear to be similar for both sexes. Age, cigarette smoking, and family history are all reported to have high association with AAA formation.,6 Women are usually older than their male counterparts when they undergo AAA repair (Tables 1 and 2). ${ }^{1,6-12}$ Men have a higher association of ischemic coronary artery disease and peripheral aneurysms (usually femoral or popliteal in location), and women have a higher incidence of concomitant aortoiliac occlusive disease. ${ }^{6}$

The decision of when to recommend repair of an AAA for women is debatable. The general consensus is that the rupture rate increases with increasing aortic diameter. The rupture rate increases dramatically as the aneurysm diameter approaches $5 \mathrm{~cm}$. Generally, when the aneurysm attains this size, treatment is recommended for low-risk patients in the United States. Similarly, a $5.5-\mathrm{cm}$ aneurysm diameter is used for this standard in the United Kingdom. Data concerning the optimal timing of repair have been generated primarily in men. Measurement of AAA diameter, combined with close analysis of the individual patient's surgical risk, has been used historically to make operative recommendations. The optimal timing of repair on the basis of aortic diameters for women has not been clearly defined. The risk-benefit analysis might be different for women. The UK Small Aneurysm Trial demonstrated a 3-fold increase in the incidence of rupture of an AAA when controlling for aneurysm size in women compared with men. ${ }^{4}$ Therefore do normal aortas differ in size between men and women? A study designed to screen the size of abdominal aortas by using ultrasonography reported significant differences in normal aortic diameter between the sexes, as well as based on body mass indices and body surface area. ${ }^{13}$ In this study a total of 122,272 men and 3450 women were screened. Normal aortic diameter differed between men and women by $0.14 \mathrm{~cm}$ (women having the smaller aortic diameter). ${ }^{13}$ This finding is statistically significant, but the absolute size difference between men and women is small.

Several studies that examined hospital data (prevalence of AAAs and subsequent surgical treatment) suggested that women are offered surgical repair of AAAs at an alarmingly lower rate than their male counterparts. ${ }^{7,10,11}$ Unfortunately, these studies could not provide further data regarding the decision not to repair the AAA. Perhaps the women decided to forego therapy. Also possible is that their aneurysms were smaller than those of their male counterparts, making risk of rupture less likely and surgical repair less beneficial on the basis of the assumptions of size and rupture 
TABLE 1. Summary of perioperative mortality after elective abdominal aortic aneurysm repair by sex

\begin{tabular}{|c|c|c|c|c|c|c|c|c|c|}
\hline Reference & $\begin{array}{c}\text { Year of } \\
\text { publication }\end{array}$ & $\begin{array}{l}\text { Years } \\
\text { data } \\
\text { collected }\end{array}$ & Data source & Men & $\begin{array}{l}\text { Mean } \\
\text { age, } \\
\text { men } \\
\text { (y) }\end{array}$ & Women & $\begin{array}{l}\text { Mean } \\
\text { age, } \\
\text { women } \\
\text { (y) }\end{array}$ & $\begin{array}{c}\text { Perioperative } \\
\text { mortality, } \\
\text { men }\end{array}$ & $\begin{array}{c}\text { Perioperative } \\
\text { mortality, } \\
\text { women }\end{array}$ \\
\hline $\begin{array}{l}\text { Heller and } \\
\text { colleagues }^{1}\end{array}$ & 2000 & 1979-1997 & $\begin{array}{l}\text { National Hospital } \\
\text { Discharge Summary }\end{array}$ & $\begin{array}{r}277137 \\
(77 \%)\end{array}$ & $73 \ddagger$ & $\begin{array}{l}81384 \\
(23 \%)\end{array}$ & $70 \ddagger$ & 5.1 & 7.7 \\
\hline $\begin{array}{l}\text { Huber and } \\
\text { colleagues }^{8}\end{array}$ & 2001 & 1994-1996 & $\begin{array}{l}\text { Nationwide Inpatient } \\
\text { Sample }\end{array}$ & $\begin{array}{l}13114 \\
(80 \%)\end{array}$ & $71^{*}$ & $\begin{array}{r}3340 \\
(20 \%)\end{array}$ & $73^{*}$ & 3.7 & $6.1^{*}$ \\
\hline $\begin{array}{l}\text { Dardik and } \\
\text { colleagues }^{9}\end{array}$ & 1999 & 1990-1995 & $\begin{array}{l}\text { Maryland Health } \\
\text { Services Cost } \\
\text { Review Commission }\end{array}$ & $\begin{array}{r}1821 \\
(78 \%)\end{array}$ & $70 \dagger$ & $\begin{array}{r}514 \\
(22 \%)\end{array}$ & $72^{*}$ & 3.2 & 4.5 \\
\hline $\begin{array}{l}\text { Lawerence and } \\
\text { colleagues }^{10}\end{array}$ & 1999 & 1990-1994 & $\begin{array}{l}\text { National Hospital } \\
\text { Discharge Summary }\end{array}$ & $\begin{array}{l}27454 \\
(85 \%)\end{array}$ & $69 \ddagger$ & $\begin{array}{r}4913 \\
(15 \%)\end{array}$ & $76 \ddagger$ & 7.0 & 6.7 \\
\hline $\begin{array}{l}\text { Katz and } \\
\text { colleagues } 7,12\end{array}$ & $1994+1997$ & 1980-1990 & $\begin{array}{l}\text { Michigan Inpatient } \\
\text { database }\end{array}$ & $\begin{array}{r}6716 \\
(82 \%)\end{array}$ & $69 *$ & $\begin{array}{r}1469 \\
(18 \%)\end{array}$ & $73^{*}$ & 6.8 & $10.7^{*}$ \\
\hline $\begin{array}{l}\text { Johnston and } \\
\text { colleagues }^{6}\end{array}$ & 1994 & 1986 & $\begin{array}{l}\text { Canadian Society } \\
\text { of Vascular Surgery } \\
\text { Registry }\end{array}$ & $\begin{array}{r}545 \\
(80 \%)\end{array}$ & $69 *$ & $\begin{array}{r}134 \\
(20 \%)\end{array}$ & $72^{*}$ & 4.4 & 5.2 \\
\hline
\end{tabular}

${ }^{*} P<.05$, comparing men and women.

†Mean age for total population. The mean age for men only was not reported.

$\ddagger P$ value not given.

TABLE 2. Summary of perioperative mortality after ruptured abdominal aortic aneurysm repair by sex

\begin{tabular}{|c|c|c|c|c|c|c|c|c|c|}
\hline Reference & $\begin{array}{l}\text { Publication } \\
\text { year }\end{array}$ & $\begin{array}{l}\text { Years } \\
\text { data } \\
\text { collected }\end{array}$ & $\begin{array}{l}\text { Data } \\
\text { source }\end{array}$ & Men & $\begin{array}{l}\text { Mean } \\
\text { age, } \\
\text { men } \\
\text { (y) }\end{array}$ & Women & $\begin{array}{l}\text { Mean } \\
\text { age, } \\
\text { women } \\
\text { (y) }\end{array}$ & $\begin{array}{c}\text { Perioperative } \\
\text { mortality, } \\
\text { men }\end{array}$ & $\begin{array}{c}\text { Perioperative } \\
\text { mortality, } \\
\text { women }\end{array}$ \\
\hline $\begin{array}{l}\text { Heller and } \\
\text { colleagues }^{1}\end{array}$ & 2000 & $1979-1997$ & $\begin{array}{l}\text { National Hospital } \\
\text { Discharge Summary }\end{array}$ & $\begin{array}{l}52507 \\
(77 \%)\end{array}$ & $72 \ddagger$ & $\begin{array}{l}15244 \\
(23 \%)\end{array}$ & $78 \ddagger$ & 41.6 & $64.8^{*}$ \\
\hline $\begin{array}{l}\text { Katz and } \\
\text { colleagues }^{7,12}\end{array}$ & $1994+1997$ & $1980-1990$ & $\begin{array}{l}\text { Michigan Inpatient } \\
\text { database }\end{array}$ & $\begin{array}{r}2719 \\
(80 \%)\end{array}$ & $72^{*}$ & $\begin{array}{r}682 \\
(20 \%)\end{array}$ & $77^{*}$ & 47.4 & $61.6^{*}$ \\
\hline $\begin{array}{l}\text { Johnston and } \\
\text { colleagues }^{6}\end{array}$ & 1994 & 1986 & $\begin{array}{l}\text { Canadian Society of } \\
\text { Vascular Surgery } \\
\text { Registry }\end{array}$ & $\begin{array}{r}126 \\
(86 \%)\end{array}$ & NR & $\begin{array}{r}20 \\
(14 \%)\end{array}$ & NR & 49.2 & 55 \\
\hline $\begin{array}{l}\text { Evans and } \\
\text { colleagues }^{11}\end{array}$ & 2000 & 1983-1995 & $\begin{array}{l}\text { Lothian Surgical } \\
\text { Audit }\end{array}$ & $\begin{array}{r}481 \\
(82 \%)\end{array}$ & $72 † \ddagger$ & $\begin{array}{r}105 \\
(18 \%)\end{array}$ & $74 † \ddagger$ & 33 & 38 \\
\hline
\end{tabular}

$N R$, Not reported.

${ }^{*} P<.05$

†Median age.

$\ddagger P$ value not given.

risk for men. Most studies demonstrated that women with AAAs are significantly older than men with AAAs when undergoing repair (Tables 1 and 2). ${ }^{6-9,12}$ Women might become older while the treatment team waits for the aneurysm to reach an absolute size before considering repair. Increased age might also dissuade either the patient or treating physician from pursuing aneurysmectomy because advanced age has been shown in some studies to portend a worse outcome. ${ }^{1,8,9,12}$

In-hospital mortality rates for elective AAA repair have been reported to be similar for men and women. A signif- icant number of large, population-based reports have been published and are summarized in Table 1. These studies again demonstrate the large difference of prevalence of AAAs in men when compared with those in women. Most studies found no difference in perioperative mortality between men and women ${ }^{1,6,9,10}$; however, several studies did demonstrate statistically significant higher mortality in women. ${ }^{7,8,12}$

Perioperative mortality after repair of a ruptured AAA is summarized in Table 2. Fewer studies examined the outcomes of ruptured AAA than elective AAA. The data from 
these reports are contradictory in terms of higher mortality in women when compared with that in men while undergoing repair of a ruptured AAA. The women were significantly older than men who receive treatment for ruptured AAA. This difference is even greater than that reported for elective AAA repair. This fact might partially, or even fully, explain the difference in mortality because age is another independent risk factor for mortality.

Endovascular repair of AAA was first introduced in 1991. ${ }^{14}$ Large volumes of commercially produced devices became available in the United States in the mid-1990s. Two devices gained US Food and Drug Administration approval in 1999, one in 2002, and another in 2003. Several reports have been published that examine the differences between men and women who underwent endovascular repair. Unfortunately, some of these studies had extremely low numbers of women evaluated and treated. It is difficult to compare outcomes for all devices because these devices are designed in unique ways that might cause different outcomes on the basis of device or patient selection alone. In addition, several devices have had modifications over time, which also makes comparisons difficult. Reports of large series of endovascular AAA repair demonstrate $11 \%$ (1018 total patients) ${ }^{15}$ and $14 \%$ (703 total patients) ${ }^{16}$ of treated patients were women. This is an even lower rate than that reported in many open surgical series. Women might not be candidates for endovascular repair because of several anatomic features. These include small access vessels, which might make passage of these large devices complex or impossible, and short, wide, and angulated aortic necks, which might prevent successful exclusion of blood flow from into the aneurysm sac. ${ }^{17}$ Most series demonstrated that a significantly higher number of women were ineligible for endovascular repair because of anatomic concerns. ${ }^{17-19}$ Despite these issues, 2 reports demonstrated no significant difference in mortality or morbidity between men and women who underwent endovascular AAA exclusion. ${ }^{17,20}$ As the technologic aspects of endografts improve, which includes smaller device profiles and greater variability in neck sizes and attachment options, more women might become eligible for endograft placement.

AAA affects significantly fewer women than men in Western nations. Women receive diagnoses and are treated at a more advanced age than similarly affected men. Women might be offered surgical repair at a significantly lower rate than men. Whether women have greater mortalities after open AAA repair (both elective and emergency) remains unclear. Women have more challenging anatomies for endovascular AAA repair, thus frequently excluding them from this treatment modality.

Future challenges include 3 important issues.
1. A need for basic research exists that would explain the striking difference in the prevalence of AAAs between men and women. If a physiologic basis for the difference is defined, important information regarding all arterial disease might be better understood.

2. Clinical research needs to be continued to determine sex-appropriate guidelines for the optimal timing of AAA repair for women and to investigate why women appear to undergo AAA repair at a lower rate than men.

3. Further technologic development of endografts might address the difficult anatomy that appears to be more common in women and make this option more available to them.

\section{References}

1. Heller JA, Weinberg A, Arons R, Krishnasastry KV, Lyon RT, Deitch JS, et al. Two decades of abdominal aortic aneurysm repair: have we made any progress? J Vasc Surg. 2000;32(6):1091-100.

2. Bengtsson $\mathrm{H}$, Bergqvist D, Sternby N-H. Increasing prevalence of abdominal aortic aneurysms. Eur J Surg. 1992;158:19-23.

3. Ernst CB. Abdominal aortic aneurysm. N Engl J Med. 1993;328:116772 .

4. Brown LC, Powell JT, for the UK Small Aneurysm Trial Participants. Risk factors for aneurysm rupture in patients kept under ultrasound surveillance. Ann Surg. 1999;230:289-97.

5. Lederle FA, Johnson GR, Wilson SE, for the Aneurysm Detection Management Veterans Affairs Cooperative Study. Abdominal aortic aneurysm in women. $J$ Vasc Surg. 2001;34:122-6.

6. Johnston KW, for the Canadian Society for Vascular Surgery Aneurysm Study Group. Influence of sex on the results of abdominal aortic aneurysm repair. J Vasc Surg. 1994;20:914-23.

7. Katz DJ, Stanley JC, Zelenock GB. Gender differences in abdominal aortic aneurysm prevalence, treatment, and outcome. J Vasc Surg. 1997;25:561-8.

8. Huber TS, Wang JG, Derrow AE, Dame DA, Ozaki CK, Zelenock GB, et al. Experience in the United States with intact abdominal aortic aneurysm repair. $J$ Vasc Surg. 2001;33:304-12.

9. Dardik A, Lin JW, Gordon TA, Williams GM, Perler BA. Results of elective abdominal aortic aneurysm repair in the 1990s: a populationbased analysis of 2335 cases. J Vasc Surg. 1999;30:985-95.

10. Lawerence PF, Gazak C, Bhirangi L, Jones B, Bhirangi K, Oderich G, et al. The epidemiology of surgically repaired aneurysms in the United States. J Vasc Surg. 1999;30:632-40.

11. Evans SM, Adam DJ, Bradbury AW. The influence of gender on outcome after ruptured abdominal aortic aneurysm. J Vasc Surg. 2000;32:258-62.

12. Katz DJ, Stanley JC, Zelenock GB. Operative mortality rates for intact and ruptured abdominal aortic aneurysms in Michigan: an eleven-year statewide experience. J Vasc Surg. 1994;19:804-17.

13. Lederle FA, Johnson GR, Wilson SE, Gordon IL, Chute EP, Littooy FN, et al. Relationship of age, gender, race and body size to infrarenal aortic diameter. J Vasc Surg. 1997;26:595-601.

14. Parodi JC, Palmaz JC, Barone HD. Transfemoral intraluminal graft implantation for abdominal aortic aneurysms. Ann Vasc Surg. 1991; 5:491-9.

15. Zarins CK, White RA, Moll FL, Crabtree T, Bloch DA, Hodgson KJ, et al. The AneuRx stent graft: four-year results and worldwide experience 2000. J Vasc Surg. 2001;33(suppl):S135-45.

16. Ouriel K, Clair DG, Greenberg RK, Lyden SP, O’Hara PJ, Sarac TP, et al. Endovascular repair of abdominal aortic aneurysms: devicespecific outcome. J Vasc Surg. 2003;37:991-8.

17. Velazquez OC, Larson RA, Baum RA, Carpenter JP, Golden MA, Mitchell ME, et al. Gender-related differences in infrarenal aortic 
aneurysm morphologic features: issues relevant to Ancure and Talent endografts. J Vasc Surg. 2001;33(suppl):S77-84.

18. Becker GJ, Kovacs M, Mathison MN, Katzen BT, Benenati JF, Zemel $\mathrm{G}$, et al. Risk stratification and outcomes of transluminal endografting for abdominal aortic aneurysm: 7-year experience and long-term follow-up. J Vasc Interv Radiol. 2001;12:1033-46.

19. Carpenter JP, Baum RA, Barker CF, Golden MA, Mitchell ME,
Velazquez OC, et al. Impact of exclusion criteria on patient selection for endovascular abdominal aortic aneurysm repair. J Vasc Surg. 2001;34:1050-4

20. Mathison M, Beck GJ, Katzen BT, Benenati JF, Zemel G, Powell A, et al. The influence of female gender on the outcome of endovascular abdominal aortic aneurysm repair. J Vasc Interv Radiol. 2001;12: 1047-51.

\section{JTCVS On-Line Manuscript Submission and Review}

\section{Please visit http://www.editorialmanager.com/jtcvs/}

Effective September 15, 2001, authors and reviewers may submit manuscripts and reviews electronically via Editorial Manager, our new Web-based system with full electronic submission, review, and status update capabilities.

As we move from paper to electronic submissions, the Editorial Office will make proxy submissions of all manuscripts accompanied by a diskette containing the electronic files of the text, tables, and figures. Editors, authors, and reviewers will receive automatic e-mails when significant events occur.

We strongly encourage all authors and reviewers to use Editorial Manager. Although we will continue to accommodate the submission of paper manuscripts for some months, our goal is to be completely electronic within 9 to 12 months.

All individuals currently in our database for whom we have e-mail addresses will receive via e-mail a system-assigned username and password that can be used to log in to the system without prior registration. All those not receiving the e-mail must register the first time they use the system.

As with any broad systemic change, the conversion to the new system will take some time to complete. We ask your patience as we replace our in-office database with the new system. We also encourage you to take advantage of the speed and efficiency that the new system will provide for us all: editor, author, reviewer, and publisher. 